J. Clin. Chem. Clin. Biochem.

Vol. 24, 1986, pp. 393-398

(C) 1986 Walter de Gruyter \& Co. Berlin - New York

\title{
Radioimmunoassay for the Measurement of Insulin-Like Growth Factor I in Patients with Pituitary Disease in Comparison with Commercially Available Somatomedin-C Radioimmunoassays
}

\author{
By Beate Pfeifle, V. Maier and H. Ditschuneit \\ Department of Internal Medicine, University of Ulm, Ulm, FRG
}

(Received July 23, 1985/February 6, 1986)

Summary: A highly sensitive and specific radioimmunoassay for the measurement of insulin-like growth factor I (IGF I) has been developed. The IGF I concentrations were measured in sera of normal subjects, patients with acromegaly, hypophysectomized patients and patients with hyperprolactinaemia. The results were compared with the results obtained after measurement of IGF I in the sera of the same patients with two commercially available radioimmunoassays for somatomedin-C.

IGF I was separated from its carrier protein using Sep-Pak C18 cartridges. The total recovery of IGF I by this method was about $100 \%$. The in-house assay shows a high specificity for IGF I and a high sensitivity. As little as $0.1 \mu \mathrm{g} / \mathrm{l}$ of IGF I can be detected. Only a small amount of serum $(25 \mu \mathrm{l})$ is necessary for the IGF I determination and a great number of serum samples (more than 100 per day) can be processed.

The mean immunoreactive IGF I concentration was $379 \pm 159 \mu \mathrm{g} / 1$ in normal adult subjects, $3340 \pm 1094 \mu \mathrm{g} / 1$ in acromegalic patients, and $52 \pm 11 \mu \mathrm{g} / \mathrm{l}$ in growth-hormone deficient patients. Patients with hyperprolactinaemia had an IGF I concentration of $433 \pm 112 \mu \mathrm{g} / \mathrm{l}$.

Die radioimmunologisische Bestimmung des insulinähnlichen Wachstumsfaktors I (IGF I) bei Patienten mit Akromegalie, Wachstumshormonmangel und Hyperprolactinämie

Vergleich der Daten mit zwei kommerziell erhältlichen Radioimmunoassays

Zusammenfassung: Wir entwickelten einen empfindlichen und spezifischen Radioimmunoassay zur Bestimmung des insulinähnlichen Wachstumsfaktors I (IGF I). Wir bestimmten die IGF I-Konzentration in Seren vọn gesunden Personen, Patienten mit Akromegalie, hypophysektomierten Patienten und Patienten mit Hyperprolactinämie und verglichen die Daten mit den Daten, die wir aus der Bestimmung der IGF IKonzentration derselben Seren mit zwei kommerziell erhältlichen Radioimmunoassays für Somatomedin-C erhalten haben.

Das IGF I wurde von seinem Trägerprotein über Sep-Pak C18-Säulen abgetrennt. Mit dieser Methode erreichten wir eine Wiederfindungsrate von fast $100 \%$. Mit diesem Radioimmunoassay können weniger als $0,1 \mu \mathrm{g} / \mathrm{l}$ IGF I nachgewiesen werden. Außerdem sind nur sehr geringe Serumvolumina $(25 \mu \mathrm{l})$ erforderlich, um eine Bestimmung durchzuführen. Wir beobachteten eine durchschnittliche IGF I-Konzentration von $379 \pm 159 \mu \mathrm{g} / \mathrm{l}$ bei gesunden erwachsenen Personen, bei Patienten mit Akromegalie lag der Durchschnittswert bei $3340 \pm 1094 \mu \mathrm{g} / \mathrm{l}$ und bei Patienten mit Wachstumshormonmangel bei $52 \pm 11 \mu \mathrm{g} / \mathrm{l}$. Bei Patienten mit Hyperprolactinämie lagen die durchschnittlichen IGF I-Werte bei $433 \pm 112 \mu \mathrm{g} / \mathrm{l}$. 


\section{Introduction}

The insulin-like growth factors or somatomedins are growth hormone-dependent polypeptides. They stimulate sulphate incorporation into cartilage, they have insulin-like activities and they stimulate growth of cultured cells $(1,2)$.

Apart from the isolation on the basis of different biological properties and the different purification procedures, recent studies document that somatomedin-C (SM-C), somatomedin-A (SM-A) and insulin-like growth factor I (IGF I) are chemically identical and indistinguishable in radioligand and biological assay systems $(3,4)$. SM-C/IGF I measurement has been used in screening for growth hormone deficiency and in contrast, high levels of SM-C/IGF I are found in acromegaly.

During recent years, radioimmunoassays for this analyte have been developed, and radioimmunoassays are now commercially available. The main problem in measuring this analyte is the presence of a serum binding protein for SM-C/IGF I. This serum binding protein is only partially saturated with IGF I (5) and consequently a radioimmunological determination of IGF I in whole serum leads to several difficulties. Therefore the conditions used for IGF I and SM$\mathrm{C}$ radioimmunoassays were different. Some authors measured IGF I in whole serum under equilibrium (6) or non-equilibrium conditions (7). Other groups have measured IGF I after separation of IGF I from its binding protein(s) by gel filtration (8) or acidethanol extraction (9).

This report describes the development of a highly sensitive and specific radioimmunoassay for IGF I and its application to sera of normal subjects, patients with acromegaly and hypophysectomized patients. IGF I was measured in sera of these patients after separation from its binding protein(s). The results obtained with this assay were compared with the results obtained after measurement of IGF I in the sera of the same patients with two commercially available radioimmunoassays for SM-C.

\section{Materials and Methods}

Pure IGF I and IGF II were kindly supplied by Dr. J. Zapf, University of Zürich, SM-C by Dr. A.J. D'Ercole, University of North Carolina, Chapel Hill. Human insulin was a gift from Eli Lilly and Company, Indianapolis. Epidermal growth factor and fibroblast growth factor were purchased from Serva, Heidelberg. Radioimmunoassays for SM-C were purchased from Nichols Institute Diagnostics, San Juan Capistrano, California 92675 (kit A) and from Immuno Nuclear Corporation, Stillwater, Minnesota 55082 (kit B). Goat anti-rabbit IgG was purchased from Miles Scientific, Bayer Diagnostics, Munich.

\section{Purification of IGF I}

IGF I was purified as described previously (10). Lyophilized human serum was extracted with acid-ethanol. The extract was precipitated with acetone-ethanol, and the precipitate was chromatographed on a Sephadex G-50 column (K50/100, Pharmacia) in $0.1 \mathrm{~mol} / 1$ acetic acid. The IGF I-containing fractions from the Sephadex G-50 column were ifurther purified by preparative isoelectric focusing over a range between $\mathrm{pH} 3.0$ and $\mathrm{pH}$ 9.0. The IGF I used to prepare the immunogen contained material which isofocused at a pI of $8.5 \pm 0.2$ and was free of immunoreactive insulin.

The IGF I used for radioimmunoassay was purified from the IGF I-containing fractions from Sephadex G-50 chromatography by FPLC-reversed phase chromatography, using a Pep RPC HR 5/5 column (Pharmacia, Uppsala).

\section{Iodination of IGF I}

IGF I, purified by FPLC-reversed phase chromatography, was iodinated by the chloramine-T method: $5 \mu \mathrm{g}$ of IGF I were

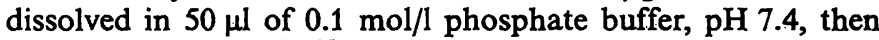
added to $37 \mathrm{MBq} \mathrm{Na}{ }^{125}$; the reaction was started by the addition of $20 \mu \mathrm{l}$ of chloramine T $(5 \mathrm{~g} / 10.1 \mathrm{~mol} / 1$ phosphate buffer). After $30 \mathrm{~s}$ the reaction was stopped by the addition of $100 \mu \mathrm{l}$ of sodium metabisulphite $(2.4 \mathrm{~g} / 10.1 \mathrm{~mol} / \mathrm{l}$ phosphate buffer) and $100 \mu \mathrm{l}$ of $\mathrm{KI}(10 \mathrm{mg} / 10.1 \mathrm{~mol} / \mathrm{l}$ phosphate buffer). The reaction mixture was chromatographed on a column of Sephadex G-25 with $0.1 \mathrm{~mol} / 1$ phosphate buffer, $\mathrm{pH} \mathrm{7.4,} \mathrm{containing}$ $2 \mathrm{~g} / 1$ human serum albumin. Before use, ${ }^{125}$ I-labelled IGF I was chromatographed on a column of Sephadex G-75 with the same buffer. $95 \%$ of the radioactivity was precipitable by $100 \mathrm{~g} / 1$ trichloroacetic acid. The specific activity of ${ }^{125}$ I-labelled IGF I was $5.55-7.4 \mathrm{MBq} / \mu \mathrm{g}$ protein.

\section{Production of antiserum}

The antigen used for immunization was prepared by conjugating IGF I to bovine serum albumin using 1-ethyl-3-(3-dimethylaminopropyl)-carbodiimide as the coupling agent. Bovine serum albumin $(3.8 \mathrm{mg})$ and IGF I preparation $(3 \mathrm{mg})$ were dissolved in $0.9 \mathrm{ml}$ of $0.1 \mathrm{~mol} / 1$ phosphate buffer, $\mathrm{pH} 7.4$. To this solution, $0.1 \mathrm{ml}$ of a 1-ethyl-3-(3-dimethylaminopropyl)carbodiimide solution $(300 \mathrm{~g} / \mathrm{l}$ phosphate buffer) was added dropwise with stirring at $20^{\circ} \mathrm{C}$ over 24 hours. The reaction mixture was then dialysed against $0.15 \mathrm{~mol} / \mathrm{l}$ sodium chloride for 16 hours.

Three chinchilla rabbits weighing approximately $4 \mathrm{~kg}$ were immunized. For the first and second injection, each rabbit received about $600 \mu \mathrm{g}$ of the IGF I bovine serum albumin complex emulsified in complete Freund's adjuvant. The subsequent injections were carried out at 3-week intervals with $100 \mu \mathrm{g}$ of the IGF I bovine serum albumin complex, emulsified in incomplete Freund's adjuvant. Ten millilitres of blood were drawn from an ear vein after 3 weeks and biweekly thereafter.

\section{Extraction of serum}

Twenty five microlitres of each serum sample were acidified with $0.5 \mathrm{ml}$ of $0.5 \mathrm{~mol} / \mathrm{l} \mathrm{HCl}$. The Sep-Pak C18 cartridge (Waters Ass., Milford, MA 01757) was washed with methanol and subsequently equilibrated with $0.5 \mathrm{~mol} / 1$ acetic acid. The serum sample was applied to the cartridge and chromatographed in $0.5 \mathrm{~mol} / 1$ acetic acid with a flow rate of $0.5 \mathrm{ml} / \mathrm{min}$. Finally IGF I was eluted with $5 \mathrm{ml}$ of methanol. The methanol was evaporated and the dried samples were then dissolved in $25 \mu \mathrm{l}$ of assay buffer and used at different dilutions in the radioimmunoassay. 


\section{Radioimmunoassay of IGF I}

The assay was carried out at $4^{\circ} \mathrm{C}$ in a phosphate/albumin buffer, $\mathrm{pH} 7.5$, containing $200 \mathrm{mg} / 1$ protamine sulphate, 4.14 g/l sodium phosphate, $2.5 \mathrm{~g} / 1$ bovine serum albumin, $3.72 \mathrm{~g} / \mathrm{l}$ EDTA and $0.2 \mathrm{~g} / \mathrm{l} \mathrm{Na-azide.} \mathrm{The} \mathrm{final} \mathrm{volume} \mathrm{of} \mathrm{the} \mathrm{reaction}$ mixture was $500 \mu \mathrm{l}$. Extracted serum sample $(50 \mu \mathrm{l})$ was added to $100 \mu$ l of $1: 10000$ diluted IGF I antiserum. After 2 hours, $100 \mu \mathrm{l}$ of ${ }^{125} \mathrm{I}$-labaled IGF I ( 30000 counts/min) was added and the mixture was incubated for another 20 hours at $4^{\circ} \mathrm{C}$, followed by the addition of $100 \mu \mathrm{l}$ of $0.1 \mathrm{~mol} / 1$ EDTA solution and $200 \mu \mathrm{l}$ of aqueous normal rabbit serum (volume fraction $0.02)$. After 1 hour, the second antibody $(100 \mu$ l of goat antirabbit gamma globulin serum, diluted $1: 4$ with assay buffer) was added and the mixture was incubated for 1 hour at $4^{\circ} \mathrm{C}$. Then $500 \mu \mathrm{l}$ of a $60 \mathrm{~g} / 1$ polyethylene glycol $\left(M_{\mathrm{r}} 6000-7500\right)$ solution was added. After $5 \mathrm{~min}$ the tubes were centrifuged (15 min, $3000 \mathrm{~min}^{-1}$ at $4^{\circ} \mathrm{C}$ ). The supernatant was poured off and the precipitate was counted in a gamma counter (1290 Gamma-Trac, Tracor Analytic). Samples were assayed in triplicate at two or more concentrations.

\section{Patients}

Most blood samples were obtained between 8 and 11 a. $\mathrm{m}$. The 108 normal adult subjects ranged in age from 24 to 65 years. None was receiving medication at the time of sampling.

The 17 acromegalic patients had elevated basal immunoreactive growth hormone levels which did not fall below $6 \mu \mathrm{g} / 1$ after the oral administration of a $100 \mathrm{~g}$ glucose load. The six patients with hyperprolactinaemia had elevated immunoassayable serum prolactin levels $(>100 \mathrm{ug} / \mathrm{l})$. The sera from 7 patients after hypophysectomy had decreased basal serum concentrations of immunoreactive growth hormone. The absence of growth hormone was demonstrated in four hypophysectomized patients.

\section{Results}

\section{Characteristics of the antiserum to IGF I}

Antibodies to IGF I were detectable in the serum of two of the three immunized rabbits 6 weeks after the first injection of IGF I. Nine weeks after the first injection a further rise of the antibody titre was observed, which remained constant during the following immunization. The antiserum was used at a $1: 10000$ dilution for the radioimmunoassay. At this dilution the antiserum bound $64 \%$ of the ${ }^{125}$ I-labelled IGF I after correction for non-specific binding. With the above incubation procedure as little as $0.1 \mu \mathrm{g} / \mathrm{l}$ of IGF I can be detected and half-maximal displacement was observed with $0.6 \mu \mathrm{g} / \mathrm{l}$ of IGF I (fig. 1). Intraassay variability, expressed as the coefficient of variation was $2.56 \%$. Interassay variability, determined by measuring the same samples in 10 assays, was $8.28 \%$.

\section{Specificity of the RIA}

Figure 1 shows the cross reactivities of IGF I (Ulm), IGF I (Zürich), IGF II, somatomedin-C, human insulin, epidermal growth factor and fibroblast growth

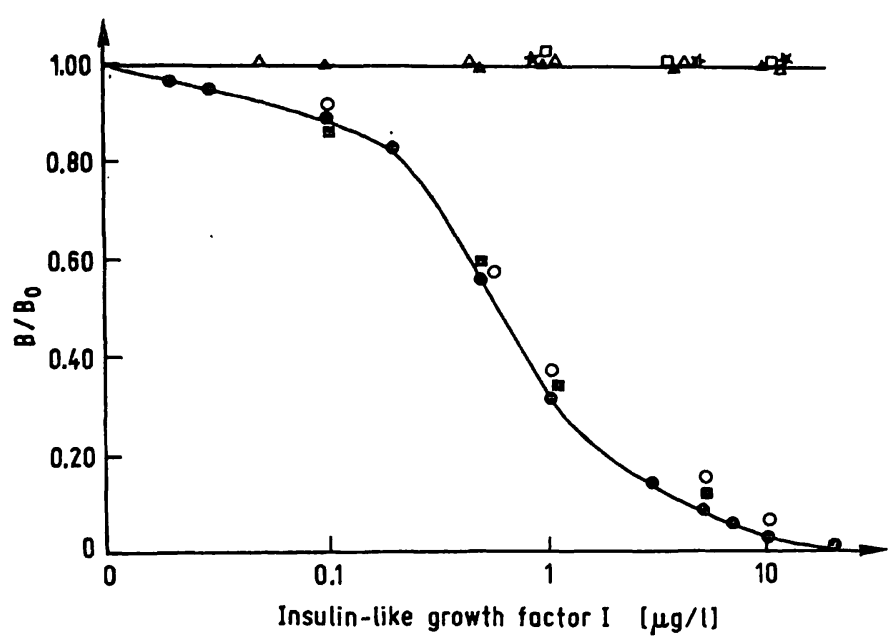

Fig. 1. Competitive inhibition of the binding of ${ }^{125}$-labelled IGF I to IGF I antiserum by unlabelled IGF I $(0-0)$, IGF I (Zürich) (0-0), SM-C (ם- $\mathbf{0})$, IGF II $(\Delta-\Delta)$, insulin $(\boldsymbol{\Delta}-\mathbf{\Delta})$, epidermal growth factor $(\square-\square)$ and fibroblast growth factor $(\star-\downarrow)$.

factor in the radioimmunoassay. The cross reactivity of IGF I (Ulm), IGF I (Zürich) and somatomedin$C$ in the radioimmunoassay was similar. No cross reactivity was observed with IGF II, human insulin, epidermal growth factor and fibroblast growth factor.

\section{IGF I RIA in extracted serum}

For our radioimmunoassay IGF I was separated from its carrier protein(s) by Sep-Pak C18 cartridges. When serum was extracted using C18 cartridges the mean IGF I concentration was $379 \pm 159 \mu \mathrm{g} / 1$ in normal subjects, $3340 \pm 1094 \mu \mathrm{g} / \mathrm{l}$ in acromegalic patients, and $52 \pm 11 \mu \mathrm{g} / \mathrm{l}$ in growth-hormone deficient patients (fig. 2). The serum IGF I concentration in six patients with hyperprolactinaemia was $433 \pm$ $112 \mu \mathrm{g} / 1$ (fig. 2).

Different dilutions of the extracted sera showed displacement curves parallel to the standard curve. Table 1 shows the IGF I values in 10 sera after different extraction procedures. The different extraction procedures were compared by measuring a total of 53 samples.

After gel chromatography of the same samples in 0.1 mol/l acetic acid, the mean IGF I level in normal subjects was lower $(198 \pm 48 \mu \mathrm{g} / \mathrm{l})$. When serum was extracted with acid-ethanol according to the method described by Daughaday et al. (9), the IGF I values were higher than those after gel chromatography. After extraction with C18 cartridges, the mean IGF I level was about $15 \%$ higher than after acid-ethanol extraction. 


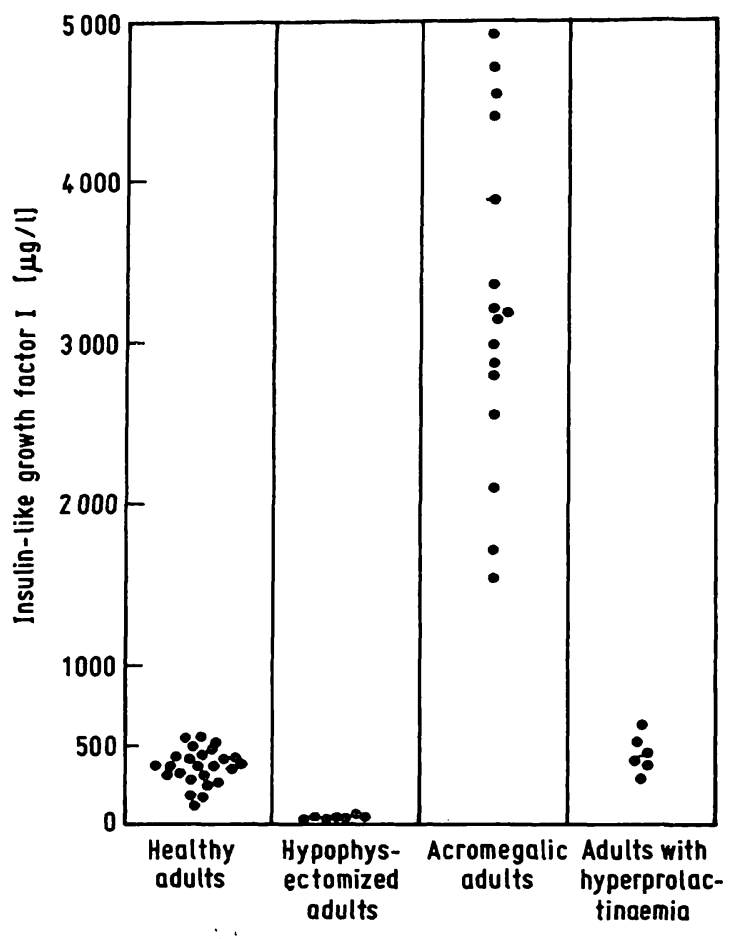

Fig. 2. Measurement of the IGF I level in sera of normal adults, hypophysectomized patients, acromegalic patients and patients with hyperprolactinaemia by the in-house assay. IGF I was separated from its carrier protein with Sep-Pak C18 cartridges.

A measurement of IGF I in unextracted serum was not possible with the above incubation procedure. The displacement curves with unextracted serum were not parallel to the standard curve. The IGF I values were dependent on the serum dilution.

Comparison of the in-house RIA with two commercial kits

The assay incubation schemes are shown in table 2 and the standard curve characteristics, including some intercept values, are demonstrated in table 3 . Table 4 shows SM-C/IGF I values, measured by the different radioimmunoassays in sera of normal subjects, acromegalic patients, hypophysectomized patients and patients with hyperprolactinaemia.

The main difference in these assays was the fact that the SM-C/IGF I concentration was measured in whole serum by kit A and in extracted serum by kit B and by the in-house method. The serum was extracted by Sep-Pak C18 cartridges in both radioimmunoassays. Furthermore, the SM-C/IGF I values were stated as $\mu \mathrm{g} / \mathrm{l}$ in the in-house method and as $U / 1$ in kit $\mathrm{A}$ and as $\mathrm{mol} / \mathrm{l}$ in kit $\mathrm{B}$.
Tab. 1. Measurement of IGF I in various sera of normal adults after different extraction procedures, using the in-house assay.

\begin{tabular}{llll}
\hline $\begin{array}{l}\text { Sample } \\
\text { No. }\end{array}$ & $\begin{array}{l}\text { Sephadex G-50 } \\
\text { chromato- } \\
\text { graphy } \\
\text { in 0.1 mol/1 } \\
\text { acetic acid } \\
\mu \mathrm{g} / 1\end{array}$ & $\begin{array}{l}\text { Acid/ethanol } \\
\text { extraction }\end{array}$ & $\begin{array}{l}\text { Extraction } \\
\text { with } \\
\text { Sep-Pak C18 } \\
\text { cartridges }\end{array}$ \\
& 169 & $\mu \mathrm{g} / 1$ & $\mu \mathrm{g} / 1$ \\
\hline 1 & 249 & 290 & 324 \\
2 & 233 & 421 & 482 \\
3 & 205 & 398 & 460 \\
4 & 215 & 347 & 398 \\
5 & 134 & 364 & 426 \\
6 & 249 & 236 & 272 \\
7 & 127 & 418 & 492 \\
8 & 149 & 225 & 266 \\
9 & 200 & 261 & 309 \\
10 & & 340 & 387 \\
\hline
\end{tabular}

Tab. 2. Assay incubation schemes.

\begin{tabular}{lccc}
\hline Step & In-house & Kit A & Kit B \\
& RIA & & \\
\hline Serum/standard $(\mu \mathrm{l})$ & 50 & 50 & 50 \\
First antibody $(\mu \mathrm{l})$ & 100 & 100 & 200 \\
Additional buffer $(\mu \mathrm{l})$ & 250 & 250 & 0 \\
Preincubation $\mathrm{h} /{ }^{\circ} \mathrm{C}$ & $2 / 4$ & $1 / \mathrm{RT}$ & $2 / 4$ \\
Tracer $(\mu \mathrm{l})$ & 100 & 100 & 200 \\
Tracer-incubation $\mathrm{h} /{ }^{\circ} \mathrm{C}$ & $20 / 4$ & $17 / 4$ & $20 / 4$ \\
Second antibody incubation & $60 / 4$ & $69 / 4$ & $120 / 4$ \\
min/ ${ }^{\circ} \mathrm{C}$ & & & \\
\hline Intercept values B/B & & & \\
\hline 0.80 & $\mu \mathrm{g} / 1$ & $\mathrm{U} / 1$ & $\mathrm{nmol} / 1$ \\
\hline .65 & 0.22 & 8.5 & 4 \\
0.50 & 0.38 & 16.5 & 7.5 \\
0.35 & 0.60 & 35.0 & 11 \\
0.20 & 0.95 & 70.0 & 15 \\
\hline
\end{tabular}

$\mathrm{RT}=$ room temperature

The intra-assay variability, expressed as the coefficient of variation was $3.97 \%$ in kit $A$ and $6.86 \%$ in kit B. The interassay variability, determined by measuring the same samples in 6 assays, was $9.82 \%$ for kit $A$ and $10.24 \%$ for kit $B$.

The sensitivity of the assays, as defined by that quantity of the standard that reduced the maximal binding of ${ }^{125}$ I-labelled SM-C/ $/ 25 I$-labelled IGF I by $10 \%$, was 4.0 U/1 SM-C for kit A, $2.2 \mathrm{~mol} / 1$ for kit B and $0.09 \mu \mathrm{g} / \mathrm{l}$ for the inhouse radioimmunoassay. The determination of SM-C with kit A was carried out with $50 \mu$ l of a $1: 20$ diluted unextracted serum. Therefore between 100 and 200 U/1 SM-C could be detected.

Using kit A, which determined the SM-C level in whole serum, the SM-C level in normal subjects was between $400 \mathrm{U} / 1$ and $1800 \mathrm{U} / 1$, in acromegalic patients 
Tab. 3. Standard curve characteristics - mean values of 3 assays.

\begin{tabular}{|c|c|c|c|c|c|c|}
\hline \multirow{2}{*}{$\begin{array}{l}\text { Parameter } \\
\text { T (counts/min) } \\
\text { UB (counts/min) }\end{array}$} & \multicolumn{2}{|c|}{ In-house RIA } & \multicolumn{2}{|c|}{ Kit A } & \multicolumn{2}{|l|}{ Kit B } \\
\hline & & & & & & \\
\hline Standards & $\begin{array}{l}\mu \mathrm{g} / 1 \\
0 \\
0.01 \\
0.1 \\
0.2 \\
0.5 \\
1 \\
3 \\
5 \\
7 \\
10 \\
20\end{array}$ & $\begin{array}{c}\text { cpm-UB } \\
18817 \\
18670 \\
16788 \\
15583 \\
10471 \\
6004 \\
2653 \\
1723 \\
1091 \\
598 \\
88\end{array}$ & $\begin{array}{r}\mathrm{U} / 1 \\
0 \\
5 \\
10 \\
25 \\
50 \\
100 \\
200\end{array}$ & $\begin{array}{l}\text { cpm-UB } \\
4438 \\
4173 \\
3376 \\
2395 \\
1874 \\
1231 \\
297\end{array}$ & $\begin{array}{c}\mathrm{nmol} / \mathrm{l} \\
0 \\
3 \\
7 \\
15 \\
30 \\
100\end{array}$ & $\begin{array}{c}\text { cpm-UB } \\
8738 \\
7395 \\
5744 \\
3086 \\
1417 \\
521\end{array}$ \\
\hline $\begin{array}{l}\mathrm{UB} / \mathrm{T} \\
\mathrm{B}_{0} / \mathrm{T}\end{array}$ & & & & & & \\
\hline
\end{tabular}

$\mathrm{UB}=$ unbound, $\mathrm{T}=$ total, $\mathrm{cpm}=$ counts $/ \mathrm{min}$

Tab. 4. Measurement of IGF I in sera of normal adults, acromegalic patients, hypophysectomized patients and patients with hyperprolactinaemia, using the in-house assay, kit $A$ and kit $B$.

\begin{tabular}{lccc}
\hline Subject No. & $\begin{array}{l}\text { In-house } \\
\text { RIA } \mu \mathrm{g} / 1\end{array}$ & $\begin{array}{c}\text { Kit A } \\
\text { U/1 }\end{array}$ & $\begin{array}{l}\text { Kit B } \\
\text { nmol/1 }\end{array}$ \\
\hline Healthy & & & \\
1 & 386 & 1000 & 12.2 \\
2 & 555 & 1100 & 24.0 \\
3 & 271 & 900 & 16.0 \\
Acromegaly & & & \\
1 & & 4000 & 100.0 \\
2 & 2541 & 4400 & 114.0 \\
3 & 2864 & 4460 & 113.5 \\
Hypophysectomy & 3127 & & \\
1 & & 240 & 7.5 \\
2 & 54 & 300 & 7.0 \\
3 & 68 & 280 & 7.2 \\
Hyperprolactinaemia & 62 & & \\
1 & & 1100 & 23.4 \\
2 & 608 & 540 & 15.6 \\
3 & 445 & 510 & 14.9 \\
\hline
\end{tabular}

it wäs between $4000 \mathrm{U} / 1$ and $6200 \mathrm{U} / 1$, in hypophysectomized patients it was between $1.90 \mathrm{U} / 1$ and $300 \mathrm{U} / 1$. The serum SM-C values in patients with hyperprolactinaemia were between $480 \mathrm{U} / \mathrm{l}$ and $1100 \mathrm{U} / \mathrm{l}$.

Using kit $B$, the SM-C level in normal subjects was between $12.2 \mathrm{nmol} / 1$ and $24.0 \mathrm{nmol} / \mathrm{l}$, in acromegalic patients it was between $60 \mathrm{nmol} / \mathrm{l}$ and $114 \mathrm{nmol} / \mathrm{l}$, in patients with hyperprolactinaemia between 12.4 $\mathrm{nmol} / \mathrm{l}$ and $23.4 \mathrm{nmol} / \mathrm{l}$ and in hypophysectomized patients between $5.8 \mathrm{nmol} / 1$ and $8.0 \mathrm{nmol} / 1$.

\section{Discussion}

This study presents a new radioimmunoassay for the measurement of IGF I.

The antibody in this assay has a great affinity for IGF I and does not recognize IGF II, and is therefore very specific.

The main problem encountered in the measurement of IGF I in serum is the fact that IGF I is bound to carrier proteins. Probably less than $1 \%$ of total IGFs circulate in a free form. Two size forms of carrier protein have been recognized in human serum. About $80 \%$ of the IGF is bound to the larger form which has a molecular weight of 150000 . The rest of the IGF is bound to a smaller form with a molecular weight of about $40000(11,12)$.

The binding of IGFs to carrier proteins is highly specific and of high affinity. Apparent association constants of $0.2-1 \mathrm{nmol} / 1$ have been described (13, $14,15)$ which are comparable to the affinity of the binding of IGF I to most of its binding sites on the cell membrane.

Since the serum carrier protein is only partially saturated with IGF I (5), the radioimmunological determination of IGF I in whole serum is complicated. The labelled IGF I may compete with the unlabelled IGF I not only for its binding sites to the antibody but also for its binding to the carrier proteins. Therefore the concentration of IGF I carrier proteins may influence the results of the radioimmunoassay.

The values obtained for IGF I in whole serum with our inhouse assay were dependent on the serum dilution. A similar observation has been described by Daughaday et al. (9) and Zapf et al. (8). 
Therefore we decided to determine IGF I in extracted serum using Sep-Pak C18 cartridges for the separation of IGF I from its carrier proteins. However, other methods for the separation of IGF I from its carrier proteins have been described.

Zapf et al. (8) separated their IGF I from its binding protein by gel chromatography, Daughaday et al. (9) extracted the serum with acid-ethanol before measuring the IGF I. The IGF I values, determined after these separation procedures, were different. The immunoreactive serum IGF I levels, measured by Zapf et al. were about $30 \%$ lower than the IGF I levels measured by Daughaday et al. after acid-ethanol extraction of the sera.

We tested these different separation procedures and found that after a separation of IGF I from its carrier protein by gel chromatography the measured IGF I values were more than $40 \%$ lower than those determined after an acid-ethanol extraction. These differences are due to a great loss of IGF I. during gel chromatography. The total recovery of exogenous IGF I added to serum was $60-65 \%$. Zapf et al. reported a total recovery by gel chromatography of $74 \%$, whereas Daughaday et al. described a total recovery of $100 \%$ by acid-ethanol extraction. After separation of IGF I from its binding protein by SepPak C18 cartridges, our measured IGF I values were $\sim 15 \%$ higher than those obtained after acid-ethanol extraction. This may be due to a loss of IGF I during our separation procedure by acid-ethanol. The total recovery after acid-ethanol treatment was $\sim 90 \%$, whereas the total recovery by Sep-Pak C18 cartridges was about $100 \%$. On the basis of the excellent recovery by the cartridge procedure we conclude that this method is superior to Sephadex chromatography.

The comparison of the in-house radioimmunoassay with kit $A$ and kit $B$ shows that the values of kit $B$ and the in-house method correlate with each other. The few discrepancies may be due to the antibody or the quality of the labelled or unlabelled IGF I itself.

The method used with kit A was described by Furlanetto et al. (7), who developed a method for IGF I/ SM-C in whole serum, using a serum pool $(1 \mathrm{U} / 1$ of IGF I) as standard. Therefore, a direct comparison of the in-house assay with this method is difficult. Since the values were given in $U / 1$, only their relationship to each other may be examined.

Our present in-house assay shows a high specificity for IGF I and a high sensitivity. As little as $0.1 \mu \mathrm{g} / 1$ of IGF I can be detected. The use of C18 cartridges for the separation of IGF I from its binding protein makes it possible to process a small amount of serum $(25 \mu \mathrm{l})$ and a great number of serum samples (more than 100 per day). The assay is suitable for routine use.

\section{Acknowledgement}

We gratefully acknowledge Dr. J. Zapfs gift of IGF I and IGF II and Dr. A. J. D'Ercole's gift of SM-C. We wish to thank Mrs Claudia Hartleb for her technical assistance.

\section{References}

1. Daughaday, W. H., Hall, K., Raben, M. S., Salmon, W. D., Van den Brande, J. L. \& Van Wyk, J. J. (1972) Nature (Lond.) 235, 107.

2. Zapf, J., Schoenle, E. \& Froesch, E. R. (1978) Eur. J. Biochem. 87, 285-296.

3. Klapper, D. G., Svoboda, M. E. \& Van Wyk, J. J. (1983) Endocrinology 112, 2215-2217.

4. Enberg, G., Carlquist, M., Jörnvall, H. \& Hall, K. (1984) Excerpta Medica, Intern. Congress Series No. 652, p. 588, Elsevier Science Publishers B. V., Amsterdam.

5. Zapf, J., Jagars, G., Sand, I. \& Froesch, E. R. (1978) FEBS Lett. 90, 135-140.

6. Reber, K. \& Liske, R. (1976) Horm. Res. 7, 201-213.

7. Furlanetto, R. W., Underwood, L. E., Van Wyk, J. J. \& D'Ercole, A. J. (1977) J. Clin. Invest. 60, 648-657.

8. Zapf, J., Walter, H. \& Froesch, E. R. (1981) J. Clin. Invest. $68,1321-1330$.

9. Daughaday, W. H., Mariz, I. K. \& Blethen, S. L. (1980) J. Clin. Endocrinol. Metab. 51, 781-788.

10. Pfeifle, B., Ditschuneit, H. H. \& Ditschuneit, H. (1982) Horm. Metabol. Res. 14, 409-414.

11. Hintz, R. L. \& Liu, F, (1977) J. Clin. Endocrinol. Metab. 45, 988-995.

12. Zapf, J., Waldvogel, M. \& Froesch, E. R. (1975) Arch. Biochem. Biophys. 168, 638-645.

13. Moses, A. C., Nissley, S. P., Passamani, J., White, R. M. \& Rechler, M. M. (1979) Endocrinology 104, 536-546.

14. Knauer, D. J,, Wagner, F. W. \& Smith, G. L. (1981) J. Supramol. Struct. Cell. Biochem. 15, 177-191.

15. White, R. M., Nissley, S. P., Moses, A. C., Rechler, M. M. \& Johnsonbaugh, R. E. (1981) J. Clin. Endocrinol: Metab. 53, 49-57.

Dr. Beate Pfeifle

Universität Ulm

Innere Medizin II

Steinhövelstr. 9

D-7900 Ulm 